\title{
The Best Digital Biomarkers Papers of 2017
}

\author{
Christopher W. Snyder ${ }^{a} \quad$ E. Ray Dorsey ${ }^{a} \quad$ Ashish Atreja $^{b}$ \\ ${ }^{a}$ Center for Health + Technology, University of Rochester Medical Center, Rochester, \\ NY, USA; b AppLab, Department of Medicine, Icahn School of Medicine at Mount Sinai, \\ New York, NY, USA
}

\section{Keywords}

Digital divide · Passive monitoring · Wearable sensors · Digital pills · Hypertension ·

Parkinson disease $\cdot$ Huntington disease $\cdot$ Chronic obstructive pulmonary disease $\cdot$ Mental health · Bipolar disorder

\section{Abstract}

The use and evaluation of digital biomarkers, objective and quantifiable measures of biology, and health collected through digital devices is growing rapidly. To highlight some of the most promising work in the field, we have compiled a list of the top digital biomarkers papers from the past year. Eligible papers reported on original research that evaluated a digital sensor (e.g., smartphone, wearable sensor, implantable device) in humans and was published in a peer-reviewed journal in 2017. Nominations were solicited from the editorial board of Digital Biomarkers and supplemented by papers the editorial team identified from Web of Science, Google Scholar, and PubMed. The editorial board then selected up to ten papers to be recognized among 28 nominations. Here, we present all of the nominated papers and profile the eight that received the most votes. The top eight papers evaluated 1,290 individuals with digital pills, smartwatches, wearable devices, and electronic inhalers in disease states ranging from dementia to diabetes and from Parkinson disease to pain. 


\begin{tabular}{|c|c|}
\hline \multicolumn{2}{|l|}{ Digit Biomark 2018;2:64-73 } \\
\hline DOI: $10.1159 / 000489224$ & $\begin{array}{l}\text { (c) } 2018 \text { The Author(s). Published by S. Karger AG, Basel } \\
\text { www.karger.com/dib }\end{array}$ \\
\hline
\end{tabular}

Snyder et al.: The Best Digital Biomarkers Papers of 2017

Table 1. Summary of the top eight digital biomarkers papers of 2017

\begin{tabular}{|c|c|c|c|c|}
\hline Reference & $\begin{array}{l}\text { Sample } \\
\text { size }\end{array}$ & $\begin{array}{l}\text { Patient population/ } \\
\text { condition }\end{array}$ & Technology & Findings \\
\hline $\begin{array}{l}\text { Urwyler } \\
\text { et al. [1] }\end{array}$ & 20 & $\begin{array}{l}\text { elderly adults with } \\
\text { dementia and } \\
\text { age-matched controls }\end{array}$ & $\begin{array}{l}\text { passive sensors } \\
\text { which monitor } \\
\text { temperature, } \\
\text { humidity, light, and } \\
\text { movement }\end{array}$ & $\begin{array}{l}\text { behavior patterns in individuals with } \\
\text { dementia are significantly more } \\
\text { disorganized than in controls }\end{array}$ \\
\hline $\begin{array}{l}\text { Silva de } \\
\text { Lima } \\
\text { et al. [2] }\end{array}$ & 953 & Parkinson disease & $\begin{array}{l}\text { smartwatch paired } \\
\text { with a smartphone } \\
\text { application }\end{array}$ & $\begin{array}{l}\text { positive feedback overall indicated that } \\
\text { large-scale wearable sensor studies in } \\
\text { individuals with Parkinson disease } \\
\text { demonstrated that such studies are } \\
\text { feasible }\end{array}$ \\
\hline $\begin{array}{l}\text { Adams } \\
\text { et al. [3] }\end{array}$ & 56 & $\begin{array}{l}\text { Parkinson disease, } \\
\text { Huntington disease, } \\
\text { prodromal Huntington } \\
\text { disease, and controls }\end{array}$ & $\begin{array}{l}\text { wearable } \\
\text { accelerometer }\end{array}$ & $\begin{array}{l}\text { individuals with Huntington disease } \\
\text { spend significantly more time lying } \\
\text { down than individuals with Parkinson } \\
\text { disease and healthy controls }\end{array}$ \\
\hline $\begin{array}{l}\text { Chai } \\
\text { et al. [4] }\end{array}$ & 10 & $\begin{array}{l}\text { acute pain due to bone } \\
\text { fracture }\end{array}$ & digital pills & $\begin{array}{l}\text { digital pills provide an efficient means } \\
\text { by which to track medication intake }\end{array}$ \\
\hline $\begin{array}{l}\text { Frias } \\
\text { et al. [5] }\end{array}$ & 109 & $\begin{array}{l}\text { uncontrolled } \\
\text { hypertension and type } 2 \\
\text { diabetes }\end{array}$ & $\begin{array}{l}\text { digital pills paired } \\
\text { with a wearable } \\
\text { sensor and a } \\
\text { smartphone } \\
\text { application }\end{array}$ & $\begin{array}{l}\text { individuals whose care was informed } \\
\text { by the digital health system reported } \\
\text { lower blood pressure than those } \\
\text { receiving standard care }\end{array}$ \\
\hline $\begin{array}{l}\text { Locatelli } \\
\text { and } \\
\text { Alimonti } \\
{[6]}\end{array}$ & 27 & $\begin{array}{l}\text { essential tremor and } \\
\text { Parkinson disease }\end{array}$ & $\begin{array}{l}\text { wearable } \\
\text { accelerometer }\end{array}$ & $\begin{array}{l}\text { tremor caused by Parkinson disease } \\
\text { could be distinguished from essential } \\
\text { tremor based on amplitude using a } \\
\text { wearable sensor }\end{array}$ \\
\hline $\begin{array}{l}\text { Shah } \\
\text { et al. [7] }\end{array}$ & 110 & COPD & $\begin{array}{l}\text { a Bluetooth-enabled } \\
\text { pulse oximeter } \\
\text { paired with a } \\
\text { smartphone } \\
\text { application }\end{array}$ & $\begin{array}{l}\text { determined that pulse rate, respiratory } \\
\text { rate, and blood oxygen level were all } \\
\text { predictive of COPD exacerbation events } \\
\text { with blood oxygen level being the most } \\
\text { predictive }\end{array}$ \\
\hline $\begin{array}{l}\text { Wen } \\
\text { et al. [8] }\end{array}$ & 5 & young adults & $\begin{array}{l}\text { wearable } \\
\text { accelerometer }\end{array}$ & $\begin{array}{l}\text { step count and distance were shown to } \\
\text { be reliable across multiple devices, } \\
\text { whereas other metrics such as energy } \\
\text { expenditure and sleep quality were not }\end{array}$ \\
\hline
\end{tabular}

COPD, chronic obstructive pulmonary disease.

\section{Overview}

The top eight digital biomarker papers of 2017 [1-8] (Table 1) tell us much about the current state, unmet needs, and future directions of the field. As shown in Figure 1, the eight studies are diverse in terms of the study population, the devices used, the data collected, the duration, the geography, the location of assessments, and the objective of the studies.

The eight studies predominantly focused on individuals with a particular disease, but the list of diseases examined (dementia, Parkinson disease, Huntington disease, acute pain, hypertension, diabetes, essential tremor, and chronic obstructive pulmonary disease [COPD]) is diverse and long. Reflecting on the growth and maturation of studies of digital biomarkers, three of the eight studies had more than 100 participants, and one had nearly 1,000 participants. Importantly, many - if not most - of the studies did not report on the demographic 


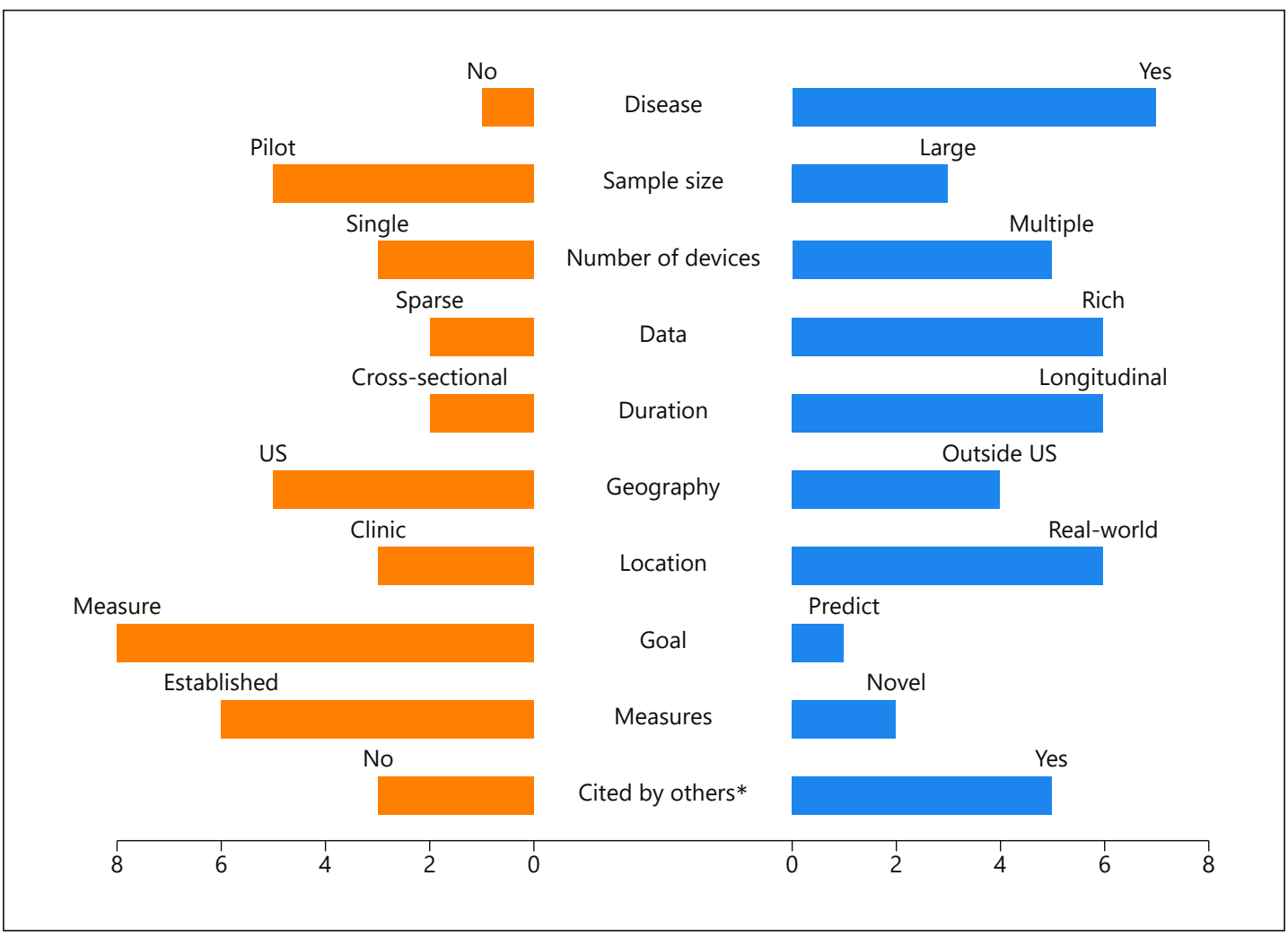

Fig. 1. Ten characteristics of the top eight publications. Note that some studies may be double counted, e.g., a study may have carried out activities both inside and outside the United States. ${ }^{*}$ Citation status based on a Google Scholar search performed on March 17, 2018.

characteristics of the study participants and the impact upon underserved populations. The "digital divide" [9], the differential access to the internet and related technologies based on economic, geographic, and social factors, is an enormous barrier to the use of digital sensors and telehealth generally [10,11]. One important study [5] in southern California that sought to empower individuals with uncontrolled hypertension and diabetes by using digital pills to track adherence, wearable sensors, and a mobile application enrolled 109 participants, of whom $46 \%$ were Hispanic, $57 \%$ had an income of less than USD 20,000, and 52\% had a high school education or less. Studies like this will be important to demonstrate the value of these digital sensors for all [11].

Just as the diseases studied were diverse, so too were the digital sensors. Among the sensors evaluated were the following: sensor boxes in the home that passively assess light, temperature, and movement; watches; wearable accelerometers; digital pills that can communicate when they have been ingested; several smartphone applications; pulse oximeters; and smart bracelets. In five of the eight studies, more than one digital tool was evaluated as part of the intervention studied. The result is that large data sets are generated even from small studies (e.g., 9,600 h of activity data from a 20-person study).

The duration of studies is also increasing. Only two of the eight studies were crosssectional, and one lasted 1 year. As most clinical measures in use today are limited to episodic, in-clinic assessments, digital biomarkers are seeking to gather data both inside and outside the clinic. Six of the eight studies, which spanned Asia, Europe, and North America, gathered health data on how people are doing in "real-world" settings. Shining light on how individuals 
Table 2. Summary of papers nominated for the top digital biomarkers papers of 2017

\begin{tabular}{llll}
\hline Reference & $\begin{array}{l}\text { Sample } \\
\text { size }\end{array}$ & $\begin{array}{l}\text { Patient population/ } \\
\text { condition }\end{array}$ & Technology \\
\hline $\begin{array}{l}\text { Barrett } \\
\text { et al. [12] }\end{array}$ & 120 & asthma & $\begin{array}{l}\text { electronic inhaler } \\
\text { paired with } \\
\text { smartphone and web } \\
\text { applications }\end{array}$
\end{tabular}

Findings

\begin{tabular}{llll}
\hline Beaulieu & not & asymptomatic & \\
et al. [13] & specified & adults & wearable \\
& & accelerometers paired \\
& & with a motion- \\
& & monitoring load \\
& & sensor
\end{tabular}

the digital asthma monitoring system led to improved asthma outcomes including increased symptom-free days and decreased use of emergency relief medications

\begin{tabular}{|c|c|c|c|c|}
\hline $\begin{array}{l}\text { Boonstra } \\
\text { et al. [14] }\end{array}$ & 63 & mental health & $\begin{array}{l}\text { smartphone } \\
\text { application with a } \\
\text { Bluetooth sensor }\end{array}$ & $\begin{array}{l}\text { smartphones enable insights into } \\
\text { the connection between social } \\
\text { network quality and mental health }\end{array}$ \\
\hline $\begin{array}{l}\text { Brogioli } \\
\text { et al. [15] }\end{array}$ & 30 & spinal cord injury & $\begin{array}{l}\text { wearable } \\
\text { accelerometer }\end{array}$ & $\begin{array}{l}\text { wearable sensors are strongly } \\
\text { correlated with standard clinical } \\
\text { metrics for rehabilitation in } \\
\text { individuals with spinal cord } \\
\text { injuries }\end{array}$ \\
\hline
\end{tabular}

\begin{tabular}{llll}
\hline $\begin{array}{l}\text { Chahine } \\
\text { et al. [16] }\end{array}$ & 27 & $\begin{array}{l}\text { Parkinson disease } \\
\text { and related } \\
\text { disorders }\end{array}$ & $\begin{array}{l}\text { specialized motor } \\
\text { monitoring device }\end{array}$ \\
\end{tabular}

\begin{tabular}{|c|c|c|c|}
\hline $\begin{array}{l}\text { Cheng } \\
\text { et al. [17] }\end{array}$ & 4 & $\begin{array}{l}\text { asymptomatic } \\
\text { adults }\end{array}$ & $\begin{array}{l}\text { wearable } \\
\text { accelerometer }\end{array}$ \\
\hline
\end{tabular}

\begin{tabular}{|c|c|c|c|}
\hline $\begin{array}{l}\text { Cheng } \\
\text { et al. [18] }\end{array}$ & 44 & Parkinson disease & $\begin{array}{l}\text { smartphone } \\
\text { accelerometer }\end{array}$ \\
\hline
\end{tabular}

A two-part sensor system was developed and tested; the system was able to detect patterns unique to four types of irregular gait

objective motor scores obtained at baseline visit were able to predict standard clinical motor scores 6

three different machine learning approaches were shown to be effective in classifying human activities such as sitting, standing, and walking from wearable accelerometer data

individuals with Parkinson disease showed lower mobility across a months later range of metrics including turn speed and duration of walking periods

\begin{tabular}{lllll}
\hline $\begin{array}{l}\text { Howcroft } \\
\text { et al. [19] }\end{array}$ & 100 & $\begin{array}{l}\text { older adults, fallers, } \\
\text { and nonfallers }\end{array}$ & $\begin{array}{l}\text { wearable } \\
\text { accelerometers }\end{array}$ & $\begin{array}{l}\text { computer-guided selection of } \\
\text { motor features improved } \\
\text { classification accuracy between } \\
\text { fallers and nonfallers }\end{array}$ \\
\hline $\begin{array}{l}\text { Place } \\
\text { et al. [20] }\end{array}$ & 73 & $\begin{array}{l}\text { PTSD and } \\
\text { depression }\end{array}$ & smartphone metadata & $\begin{array}{l}\text { smartphone-derived metrics } \\
\text { correlated well with clinically } \\
\text { assessed features of PTSD and } \\
\text { depression }\end{array}$ \\
\hline $\begin{array}{l}\text { Caramia } \\
\text { et al. [21] }\end{array}$ & 10 & young adults who & inertial measurement & $\begin{array}{l}\text { young adults walk more slowly and } \\
\text { irregularly while using a } \\
\text { smartphone }\end{array}$ \\
\hline $\begin{array}{l}\text { Daudet } \\
\text { et al. [22] }\end{array}$ & $\sim 2,500$ & speech & & $\begin{array}{l}\text { metrics derived from recorded } \\
\text { speech are predictive of } \\
\text { concussions in youth athletes }\end{array}$ \\
\hline
\end{tabular}


Table 2 (continued)

\begin{tabular}{|c|c|c|c|c|}
\hline Reference & $\begin{array}{l}\text { Sample } \\
\text { size }\end{array}$ & $\begin{array}{l}\text { Patient population/ } \\
\text { condition }\end{array}$ & Technology & Findings \\
\hline $\begin{array}{l}\text { Levendowski } \\
\text { et al. [23] }\end{array}$ & 100 & sleep & $\begin{array}{l}\text { electroencepha- } \\
\text { lography }\end{array}$ & $\begin{array}{l}\text { an automatic, self-administered, } \\
\text { at-home sleep staging software } \\
\text { was shown to be as accurate as a } \\
\text { sleep technologist }\end{array}$ \\
\hline $\begin{array}{l}\text { Ligorio } \\
\text { et al. [24] }\end{array}$ & 15 & general & $\begin{array}{l}\text { magnetic inertial } \\
\text { sensors }\end{array}$ & $\begin{array}{l}\text { the required calibration stage for } \\
\text { magnetic high-precision elbow } \\
\text { movement measurement was } \\
\text { made easier, allowing the process } \\
\text { to be completed with minimal user } \\
\text { input }\end{array}$ \\
\hline $\begin{array}{l}\text { McKnight } \\
\text { et al. [25] }\end{array}$ & 297 & bipolar disorder & $\begin{array}{l}\text { smartphone } \\
\text { application }\end{array}$ & $\begin{array}{l}\text { females with bipolar disorder } \\
\text { reported more manic and } \\
\text { depressive episodes than males; } \\
\text { younger individuals reported more } \\
\text { manic episodes than older adults }\end{array}$ \\
\hline $\begin{array}{l}\text { Mitsi } \\
\text { et al. [26] }\end{array}$ & 38 & Parkinson disease & tablet application & $\begin{array}{l}\text { application-derived metrics were } \\
\text { able to distinguish individuals with } \\
\text { Parkinson disease from controls }\end{array}$ \\
\hline $\begin{array}{l}\text { Trujillo- } \\
\text { Priego et } \\
\text { al. [27] }\end{array}$ & 33 & infants & $\begin{array}{l}\text { wearable } \\
\text { accelerometer }\end{array}$ & $\begin{array}{l}\text { the algorithm developed in this } \\
\text { study identified motor } \\
\text { development trends over the first } \\
\text { year of life }\end{array}$ \\
\hline $\begin{array}{l}\text { Pepa } \\
\text { et al. [28] }\end{array}$ & 11 & adults & $\begin{array}{l}\text { smartphone } \\
\text { accelerometer }\end{array}$ & $\begin{array}{l}\text { smartphone-derived gait metrics } \\
\text { correlated strongly with gold } \\
\text { standard gait analysis technology }\end{array}$ \\
\hline $\begin{array}{l}\text { Saeb } \\
\text { et al. [29] }\end{array}$ & 208 & general & $\begin{array}{l}\text { smartphone } \\
\text { accelerometer }\end{array}$ & $\begin{array}{l}\text { smartphones can be effective sleep } \\
\text { monitoring devices, but their } \\
\text { accuracy is limited by } \\
\text { environmental factors }\end{array}$ \\
\hline $\begin{array}{l}\text { Szanto } \\
\text { et al. [30] }\end{array}$ & 13,890 & lung cancer & $\begin{array}{l}\text { smartphone } \\
\text { application }\end{array}$ & $\begin{array}{l}\text { smartphone applications provide } \\
\text { an efficient means for gathering } \\
\text { large amounts of health data on a } \\
\text { global scale; } 82 \% \text { of users who } \\
\text { smoked reported smoking }>5 \\
\text { cigarettes/day }\end{array}$ \\
\hline $\begin{array}{l}\text { Knell } \\
\text { et al. [31] }\end{array}$ & 238 & $\begin{array}{l}\text { asymptomatic } \\
\text { adults }\end{array}$ & $\begin{array}{l}\text { wearable } \\
\text { accelerometer paired } \\
\text { with a smartphone } \\
\text { application }\end{array}$ & $\begin{array}{l}\text { smartphone-based activity } \\
\text { reporting predicted sensor-derived } \\
\text { activity estimates more accurately } \\
\text { than traditional patient report } \\
\text { methods }\end{array}$ \\
\hline
\end{tabular}

PTSD, posttraumatic stress disorder.

function in the $99.9 \%$ of their lives that they are not in hospitals or clinics is one of the great promises of these digital tools. The top paper by Urwyler et al. [1] demonstrated this promise by documenting the fragmented lives individuals with dementia lead at home.

Importantly, the studies are seeking to not only replicate what is currently measured in the clinic, but also generate novel measures of health and disease. Among these novel measures are the time individuals spend lying down. In Huntington disease, a rare genetic disorder, Adams et al. [3] found that ambulatory individuals with the condition who are well enough to 
Snyder et al.: The Best Digital Biomarkers Papers of 2017

come to the clinic spend half their days at home lying down, a previously unknown finding. In addition, digital biomarkers are not only measuring health but predicting it as well. Shah et al. [7] used the data from digital sensors to predict COPD exacerbations. While their results were modest, future efforts will build upon theirs to help prevent disease before it occurs. With recent approval of reimbursement codes for remote monitoring and patient-generated data in the United States, many of the validated novel digital biomarkers now have pathway to make into clinical practice in the near future.

Finally, the value of these papers - and thus digital biomarkers - is increasingly recognized. Of the eight top papers published in 2017, five have already been cited by early 2018, and one [8] already has ten citations. We list the profiles of the top eight papers and provide an overview of all the nominated papers (Table 2).

\section{Profiles of the Top Eight Digital Biomarkers Papers of 2017}

\section{Urwyler et al. [1]}

Hands free sensors can quantify the erratic daily life of individuals with dementia. This study evaluated the use of passive monitoring systems for identifying activities of daily living in 10 individuals with Alzheimer disease and 10 age-matched controls over 20 consecutive days encompassing 9,600 h of activity data. The passive monitoring system consisted of a series of sensor boxes capable of detecting light, temperature, humidity, movement, and acceleration. Placed at strategic locations around the participants' homes, these sensor boxes distinguished eight activities of daily living including sleeping, grooming, and eating. Visualized activity maps of individuals with dementia demonstrated disorganized behavior and significant heterogeneity. Their lives are fragmented and, in comparison to those without dementia, far less predictable. After 20 days, the sensors could differentiate those with dementia from those without with an accuracy of $95 \%$.

As the authors point out, "[The] functional capability of dementia patients is traditionally assessed using questionnaires in a brief clinical visit. In contrast, sensor-based measurement systems allow to continuously monitor patients in their natural environment." They conclude, "[Sensor-based] recognition systems over the long run can help to make 'aging in place' a possibility for elderly people and patients suffering from dementia."

Silva de Lima et al. [2]

The largest wearable sensor study in Parkinson disease to date has opened the door to a new class of clinical research. A total of 954 participants were recruited across two populations in the Netherlands $(n=304)$ and in North America $(n=649)$. Each participant received a Pebble smartwatch which interfaced with the individual's own Android smartphone that supported a companion smartphone application from the Michael J. Fox Foundation that tracked activity, sleep, medication administration, and participant-reported rating of their symptoms such as tremor. Nearly $85 \%$ of the participants contributed study data, and compliance was $68 \%$, with participants using the devices for 15-16 h daily. It was encouraging to see that data contribution was not affected by demographics, clinical characteristics, or attitude towards technology. Self-reported depression was associated with lower compliance. By combining the precision of wearable sensors with the statistical power enabled by large sample sizes, studies like this are poised to reveal powerful insights into Parkinson disease. 


\section{Adams et al. [3]}

Wearable sensors are unlocking the unexplored world of Huntington and Parkinson disease. Current rating scales for Huntington disease, a rare genetic disorder that causes involuntary movements, dementia, and behavior changes, and Parkinson disease almost ignore how these conditions affect individuals in real-world settings. In this study, 56 individuals with Huntington disease, prodromal Huntington disease (individuals who carry the genetic expansion for the disease but do not have clinical symptoms), Parkinson disease, and controls spent 2 days wearing five accelerometers from MC10 on their chest and four limbs. Sensor-enabled activity monitoring revealed that individuals with Huntington disease spend $50 \%$ of their time lying down, substantially more than individuals with Parkinson disease $(38 \%)$ or those without a movement disorder (34\%). Individuals with these movement disorders also had more sleep transitions than controls. This study demonstrated the ability to capture entirely new insights into diseases that are missed during in-clinic assessments, shows the feasibility of assessing individuals with prodromal disease (which will be increasingly important as therapies look to prevent disease), and lays the foundation for longitudinal assessments with sensors with increasing functionality.

Chai et al. [4]

Digital pills could help fight the opioid crisis. Digital pills emit a radiofrequency that can be detected by smartphones to measure ingestion and inform clinicians and others of the dose, timing, and duration of opioid use. An efficient means of tracking the actual use of prescribed medications could give healthcare providers the ability to detect opioid abuse before addiction sets in. To this end, emergency room physicians prescribed oxycodone pills that were encapsulated with a sensor that was activated by gastric chloride and signaled ingestion to a hip-worn receiver to 10 individuals with acute pain due to a bone fracture. After 1 week of monitoring, the digital pill system was $87.3 \%$ accurate in detecting ingestion events as measured by pill counts. Eight (80\%) rated the system highly acceptable, and $9(90 \%)$ reported willingness to use the digital pills to improve adherence monitoring. Digital pills could reshape monitoring of pain medications and multiple other therapies (e.g., for hepatitis $\mathrm{C}$, tuberculosis, experimental medications) where adherence is critical.

Frias et al. [5]

The damaging effects of hypertension could be offset by a novel method for prescribing medicine. Despite the availability of effective medications, outcomes are marred by poor patient adherence and the lack of patient involvement. This study focused on the effect of an ingestible sensor pill, a wearable activity patch, a mobile application, and a portal for clinicians. In a pilot study, thirteen outpatient clinics in California with large numbers of patients with hypertension and diabetes were randomized to use the digital tools for 4 weeks, 12 weeks, or to no intervention. The patients in the clinics that were randomized to receive the digital tools had a greater reduction in their blood pressure and were more likely to achieve their blood pressure goal. Over $90 \%$ of participants thought that the tools were easy to learn and to incorporate into their daily routine and that they improved their health.

Locatelli et al. [6]

A faster, cheaper means of diagnosing movement disorders using wearable sensors is now within reach. Both essential tremor and Parkinson disease can cause tremor, and differentiating between the two can be challenging clinically. In this pilot study of 11 individuals with essential tremor and 16 with Parkinson disease, a wearable sensor with a gyroscope, an accelerometer, and a magnetometer worn on the hand found small differences in tremor frequency and amplitude in the two conditions that differed from tasks performed in the 
clinic. The decision tree, which was selected as the best classifier for an automatic scoring system of tremor severity, achieved the highest accuracy of $86 \%$ and a normalized area under the curve of 0.98 .

\section{Shah et al. [7]}

Lifesaving insights into COPD have been enabled through the marriage of a smartphone application and a portable pulse oximeter. This study aimed to measure the efficacy of a digital health system in predicting COPD exacerbations. The EDGE digital health system employed in this study consisted of an internet-enabled tablet computer, a customized COPD application and digital diary, and a Bluetooth-enabled pulse oximeter. The 12-month study recruited 110 patients to complete data logging sessions consisting of a short digital survey and recording about 2 min of pulse oximeter data. During the study, 27,260 of these sessions were complete over 35,000 monitoring days. Researchers were able to identify a prodromal state consisting of decreased oxygen saturation and increased heat and respiratory rate, which was predictive of an upcoming exacerbation. On the basis of the classifier developed in this work, the authors stated that the prediction of COPD exacerbation episodes with $60-80 \%$ sensitivity will result in 36-68\% specificity. While still early, this technology allows us to learn how digital biomarkers can be further refined or developed for this widely prevalent condition.

Wen et al. [8]

Can you trust what that commercial sensor is telling you? This study focused on the crossvalidation of ten commercially available wearable sensors. Five healthy participants were outfitted with two smartwatches (Samsung Gear S and Apple Watch), four smart bracelets (FitBit Surge, Jawbone Up3, Mi Band, and TalkBand B2), and four mobile health monitoring applications (Pacer, Ledongli, Samsung S Health applications, and Apple Health applications) over 5 days. The number of steps, distance, activity duration, energy expenditure, sleep duration, and deep sleep duration were compared to each other. Step count and distance were consistent across all platforms, while other metrics such as energy expenditure, sleep quality, and activity duration lacked consistency. The authors concluded, "[The] current mainstream devices are only reliable in measuring the number of steps and distance. However, the measurement consistencies of activity duration (energy expenditure), sleep quality, and so on, are still inadequate." This validation of step count and distance measurement across major commercially available wearable sensors is a major step forward to wider adoption among researchers as well as clinical practice.

\section{Disclosure Statement}

E. Ray Dorsey has received honoraria for speaking at American Academy of Neurology courses; received compensation for consulting activities from 23andMe, Clintrex, GlaxoSmithKline, Grand Rounds, Lundbeck, MC10, MedAvante, Medico Legal services, the National Institute of Neurological Disorders and Stroke, Shire, Teva, and UCB; received research support from AMC Health, Burroughs Wellcome Fund, Davis Phinney Foundation, Duke University, GlaxoSmithKlineGreat Lakes Neurotechnologies, Greater Rochester Health Foundation, Huntington Study Group, Michael J. Fox Foundation, National Science Foundation, Patient-Centered Outcomes Research Institute, Prana Biotechnology, Raptor Pharmaceuticals, Roche, Safra Foundation, University of California Irvine; and stock options from Grand Rounds. Christopher W. Snyder and Ashish Atreja have no conflicts of interest to disclose. 


\begin{tabular}{l|l}
\hline Digit Biomark 2018;2:64-73 \\
\hline DOI: 10.1159/000489224 & $\begin{array}{l}\text { ( 2)18 The Author(s). Published by S. Karger AG, Basel } \\
\text { www.karger.com/dib }\end{array}$ \\
\hline
\end{tabular}

Snyder et al.: The Best Digital Biomarkers Papers of 2017

\section{References}

1 Urwyler P, Stucki R, Rampa L, Müri R, Mosimann UP, Nef T: Cognitive impairment categorized in communitydwelling older adults with and without dementia using in-home sensors that recognise activities of daily living. Sci Rep 2017;7:42084.

-2 Silva de Lima AL, Hahn T, Evers LJW, de Vries NM, Cohen E, Afek M, Bataille L, Daeschler M, Claes K, Boroojerdi B, Terricabras D, Little MA, Baldus H, Bloem BR, Faber MJ: Feasibility of large-scale deployment of multiple wearable sensors in Parkinson's disease. PLoS One 2017;12:e0189161.

-3 Adams JL, Dinesh K, Xiong M, Tarolli CG, Sharma S, Sheth N, Aranyosi AJ, Zhu W, Goldenthal S, Biglan KM, Ray Dorsey E, Sharma G: Multiple wearable sensors in Parkinson and Huntington disease individuals: a pilot study in clinic and at home. Digit Biomark 2017;1:52-63.

4 Chai PR, Carreiro S, Innes BJ, Rosen RK, O’Cleirigh C, Mayer KH, Boyer EW: Digital pills to measure opioid ingestion patterns in emergency department patients with acute fracture pain: a pilot study. J Med Internet Res 2017;19:e19.

-5 Frias J, Virdi N, Raja P, Kim Y, Savage G, Osterberg L: Effectiveness of digital medicines to improve clinical outcomes in patients with uncontrolled hypertension and type 2 diabetes: prospective, open-label, clusterrandomized pilot clinical trial. J Med Internet Res 2017;19:e246.

6 Locatelli P, Alimonti D: Differentiating essential tremor and Parkinson's disease using a wearable sensor - a pilot study. -2017 7th IEEE International Workshop on Advances in Sensors and Interfaces (IWASI), Vieste, 2017, pp 213-218.

7 Shah SA, Velardo C, Farmer A, Tarassenko L: Exacerbations in chronic obstructive pulmonary disease: identification and prediction using a digital health system. J Med Internet Res 2017;19:e69.

8 Wen D, Zhang X, Liu X, Lei J: Evaluating the consistency of current mainstream wearable devices in health monitoring: a comparison under free-living conditions. J Med Internet Res 2017;19:e68.

9 Norris P: Digital Divide: Civic Engagement, Information Poverty, and the Internet Worldwide. Cambridge, UK, Cambridge University Press, 2001.

10 Dorsey ER, Topol EJ: State of telehealth. N Engl J Med 2016;375:154-161.

11 Digital Divide. Pew Research Center Internet Science Tech RSS, September 11, 2017. www.pewinternet.org/ topics/digital-divide/.

12 Barrett MA, Humblet O, Marcus JE, Henderson K, Smith T, Eid N, Sublett JW, Renda A, Nesbitt L, van Sickle D, Stempel D, Sublett JL: Effect of a mobile health, sensor-driven asthma management platform on asthma control. Ann Allergy Asthma Immunol 2017;119:415-421.e1.

13 Beaulieu A, Lapointe A, Givigi S, Sillins K, Lavoie A, Tilley K, Le Bel N: Network of wireless medical devices to assess the gait of rehabilitation in patients for walking and running. -2017 Annual IEEE International Systems Conference (SysCon), Montreal, QC, 2017, pp 1-8.

14 Boonstra TW, Werner-Seidler A, O'Dea B, Larsen ME, Christensen H: Smartphone app to investigate the relationship between social connectivity and mental health. 2017 39th Annual International Conference of the IEEE Engineering in Medicine and Biology Society (EMBC), Seogwipo, 2017, pp 287-290.-

15 Brogioli M, Popp WL, Schneider S, Albisser U, Brust AK, Frotzler A, Starkey ML: Multi-day recordings of wearable sensors are valid and sensitive measures of function and independence in human spinal cord injury. J Neurotrauma 2017;34:1141-1148.

-16 Chahine LM, Uribe L, Hogarth P, McNames J, Siderowf A, Marek K, Jennings D: Portable objective assessment of upper extremity motor function in Parkinson's disease. Parkinsonism Relat Disord 2017;43:61-66.

17 Cheng L, Guan Y, Zhu K, Li Y: Recognition of human activities using machine learning methods with wearable sensors. 2017 IEEE 7th Annual Computing and Communication Workshop and Conference (CCWC), Las Vegas, NV, 2017, pp 1-7.-

18 Cheng WY, Lipsmeier F, Scotland A, Creagh A, Kilchenmann T, Jin L, Siebourg-Polster J: Smartphone-based continuous mobility monitoring of Parkinsons disease patients reveals impacts of ambulatory bout length on gait features. 2017 IEEE Life Sciences Conference (LSC), Sydney, NSW, 2017, pp 166-169.-

19 Howcroft J, Kofman J, Lemaire ED: Feature selection for elderly faller classification based on wearable sensors. J Neuroeng Rehabil 2017;14:47.

20 Place S, Blanch-Hartigan D, Rubin C, Gorrostieta C, Mead C, Kane J, Marx BP, Feast J, Deckersbach T, Pentland AS, Nierenberg A, Azarbayejani A: Behavioral indicators on a mobile sensing platform predict clinically validated psychiatric symptoms of mood and anxiety disorders. J Med Internet Res 2017;19:e75.

-21 Caramia C, Bernabucci I, D’Anna C, De Marchis C, Schmid M: Gait parameters are differently affected by concurrent smartphone-based activities with scaled levels of cognitive effort. PLoS One 2017;12:e0185825.

22 Daudet L, Yadav N, Perez M, Poellabauer C, Schneider S, Huebner A: Portable mTBI assessment using temporal and frequency analysis of speech. IEEE J Biomed Health Inform 2017;21:496-506.

-23 Levendowski DJ, Ferini-Strambi L, Gamaldo C, Cetel M, Rosenberg R, Westbrook PR: The accuracy, night-tonight variability, and stability of frontopolar sleep electroencephalography biomarkers. J Clin Sleep Med 2017; 13:791-803.

24 Ligorio G, Zanotto D, Sabatini AM, Agrawal SK: A novel functional calibration method for real-time elbow joint angles estimation with magnetic-inertial sensors. J Biomech 2017;54:106-110. 
25 McKnight RF, Bilderbeck AC, Miklowitz DJ, Hinds C, Goodwin GM, Geddes JR: Longitudinal mood monitoring in bipolar disorder: course of illness as revealed through a short messaging service. J Affect Disord 2017;223: 139-145.

-26 Mitsi G, Mendoza EU, Wissel BD, Barbopoulou E, Dwivedi AK, Tsoulos I, Stavrakoudis A, Espay AJ, Papapetropoulos S: Biometric digital health technology for measuring motor function in Parkinson's disease: results from a feasibility and patient satisfaction study. Front Neurol 2017;8:273.

27 Trujillo-Priego IA, Lane CJ, Vanderbilt DL, Deng W, Loeb GE, Shida J, Smith BA: Development of a wearable sensor algorithm to detect the quantity and kinematic characteristics of infant arm movement bouts produced across a full day in the natural environment. Technologies (Basel) 2017;5:39.

28 Pepa L, Verdini F, Spalazzi L: Gait parameter and event estimation using smartphones. Gait Posture 2017;57: 217-223.

29 Saeb S, Cybulski TR, Schueller SM, Kording KP, Mohr DC: Scalable passive sleep monitoring using mobile phones: opportunities and obstacles. J Med Internet Res 2017;19:e118.

30 Szanto Z, Benko I, Jakab L, Szalai G, Vereczkei A: The use of a smartphone application for fast lung cancer risk assessment. Eur J Cardiothorac Surg 2017;51:1171-1176.

-31 Knell G, Gabriel KP, Businelle MS, Shuval K, Wetter DW, Kendzor DE: Ecological momentary assessment of physical activity: validation study. J Med Internet Res 2017;19:e253. 